\title{
Comparative studies of immunity proteins of pediocin-like bacteriocins
}

\author{
Gunnar Fimland, ${ }^{1}$ Vincent G. H. Eijsink ${ }^{2}$ and Jon Nissen-Meyer ${ }^{1}$
}

\begin{abstract}
1 Department of Biochemistry, University of Oslo, Blindern, 0316 Oslo, Norway

2 Department of Chemistry and Biotechnology, Agricultural University of Norway, Ås, Norway
\end{abstract}

\author{
Author for correspondence: Gunnar Fimland. Tel: +47 228573 51. Fax: +47 22854443. \\ e-mail: gunnar.fimland@biokjemi.uio.no
}

\begin{abstract}
Genes encoding pediocin-like bacteriocins are usually co-transcribed with a gene encoding a cognate immunity protein. To investigate the functionality and specificity of immunity proteins, immunity genes belonging to the bacteriocins curvacin $A$, enterocin $A$, enterocin $P$, leucocin $A$, pediocin PA-1 and sakacin $P$, as well as a putative immunity gene, orf $Y$, were expressed in three bacteriocin-sensitive lactic acid bacteria (Lactobacillus sake, Carnobacterium piscicola and Enterococcus faecalis). The transformed indicator strains, each containing one of the immunity genes, were tested for sensitivity towards seven different purified bacteriocins (curvacin $A$, enterocin $A$, enterocin $P$, leucocin A, leucocin $C$, pediocin PA-1 and sakacin $P$ ). Cross-immunity was observed almost exclusively in situations where either the bacteriocins or the immunity proteins belonged to the same sequence-based subgroup. In a few cases, the functionality of immunity proteins was strain-dependent; e.g. the leucocin A immunity gene provided immunity to enterocin A, pediocin PA-1 and leucocin $A$ in Ent. faecalis, whereas in the other two indicators, this gene provided immunity to leucocin A only. The orfY gene, which is transcribed without a cognate bacteriocin, was shown to encode a functional immunity protein that expands the bacteriocin resistance of the strain possessing this gene. The results show that the bacteriocin sensitivity of a lactic acid bacterium strain can depend on (1) the presence of immunity genes in connection with its own bacteriocin production, (2) the presence of extra immunity genes and (3) more general properties of the strain such as the membrane composition or the presence of receptors.
\end{abstract}

Keywords: bacteriocin resistance, lactic acid bacteria

\section{INTRODUCTION}

Many bacteria are known to produce antimicrobial peptides, termed bacteriocins (Nes et al., 2002). For example, many lactic acid bacteria (LAB) produce socalled pediocin-like bacteriocins (class IIa; Nes et al., 2002), which are structurally related cationic peptides that contain 37-48 amino acids, display anti-listerial activity and kill target cells by membrane permeabilization (Chikindas et al., 1993; Ennahar et al., 2000; Nes et al., 2002). Pediocin-like bacteriocins are further characterized by having similar amino acid sequences and a YGNGV-motif in their N-terminal regions (Ennahar et al., 2000; Nes et al., 2002). Bacteriocin-producers are

Abbreviation: $L A B$, lactic acid bacteria. protected from their own bacteriocin by the concomitant expression of a cognate immunity protein (Axelsson \& Holck, 1995; Dayem et al., 1996; Hühne et al., 1996; Quadri et al., 1995, 1997; Venema et al., 1995). The immunity gene is generally located next to, and downstream from, the bacteriocin gene, and the two genes constitute an operon, which may or may not contain other genes that are involved in bacteriocin production (Nes et al., 2002). This co-transcription is readily illustrated in regulated bacteriocin production systems where the sensitivity of the bacteriocin producer varies according to the bacteriocin production state (Eijsink et al., 1998; Quadri et al., 1997).

Putative immunity genes that have sequence similarities to the immunity genes of pediocin-like bacteriocins, but are not transcriptionally coupled to a bacteriocin gene, have been described; examples are dvnT2 (Métivier et 
al., 1998), orf- $\beta 3$ (Quadri et al., 1994) and orfY (Brurberg et al., 1997). In total, the primary structures of at least 17 immunity proteins from the pediocin family have been deduced from DNA sequences (Axelsson \& Holck, 1995; Aymerich et al., 1996; Brurberg et al., 1997; Cintas et al., 1997; Fremaux et al., 1995; Hastings et al., 1991; Hühne et al., 1996; Kalmokoff et al., 2001; Le Marrec et al., 2000; Marugg et al., 1992; Métivier et al., 1998; Quadri et al., 1994; Tomita et al., 1996; GenBank accession no. AF275938). Their size ranges from 81 to 115 amino acid residues, and they display 5-85\% sequence similarity (Eijsink et al., 1998). Functional analysis of two immunity proteins conferring immunity to mesentericin Y105 and carnobacteriocin B2 has shown that these immunity proteins are located intracellularly and that their intracellular pool is divided into a minor membrane-associated fraction and a major cytoplasmic fraction (Dayem et al., 1996; Quadri et al., 1995). The mode of action of these immunity proteins is not well known. Published results indicate that immunity proteins belonging to the pediocin family as well as the immunity protein of the non-pediocin-like class II bacteriocin lactococcin A do not interact directly with bacteriocins, at least not in aqueous solutions (NissenMeyer et al., 1993; Quadri et al., 1995; Venema et al., 1994). It has also been pointed out that the intracellular immunity protein is unlikely to act by directly preventing binding of the (extracellular) bacteriocin to the membrane (Quadri et al., 1995). On the basis of these observations, it has been suggested that immunity proteins act either by disturbing the process of bacteriocin aggregation and pore formation or by disturbing the interaction between the bacteriocin and a (putative) membrane-located bacteriocin receptor (Nissen-Meyer et al., 1993; Quadri et al., 1995; Venema et al., 1994). Concerning the latter option, it is relevant to note that recent work indicates that the action of pediocin-like bacteriocins indeed depends on the presence of certain membrane proteins involved in sugar transport (Dalet $e t$ al., 2000, 2001; Héchard et al., 2001; Ramnath et al., 2000; Yan et al., 2000).

Despite the fact that pediocin-like bacteriocins share a number of sequence characteristics, their immunity proteins display a large sequence variation. In fact, the sequence similarities between two immunity proteins may be small even though their corresponding bacteriocins may be very similar, and vice versa (Eijsink et al., 1998; Nes \& Holo, 2000). Thus, it is not possible to understand or predict the functionality of a particular immunity protein on the basis of its sequence. For example, one cannot predict to what extent an immunity protein belonging to one pediocin-like bacteriocin will give immunity to other pediocin-like bacteriocins ('cross-immunity'). To gain more insight into this matter, we have studied the functionality of seven different immunity proteins by heterologously expressing their genes in three different bacteriocin-sensitive strains. In addition to revealing protection patterns of these immunity proteins in three genetic backgrounds, the results also provide some clues as to which factors may determine large differences in bacteriocin sensitivity between closely related LAB.

\section{METHODS}

Bacterial strains, plasmids and media. The bacteriocin producer strains used in this study were Lactobacillus curvatus LTH1174 producing curvacin A (Tichaczek et al., 1993), Enterococcus faecium CTC492 producing enterocin A and enterocin B (Aymerich et al., 1996), Ent. faecium P13 producing enterocin P (Cintas et al., 1997), Leuconostoc mesenteroides 6 producing leucocins A and C (Vaughan et al., 2001) and Pediococcus acidilactici LMG 2351 producing pediocin PA-1 (Nieto Lozano et al., 1992). Sakacin P was produced by the two-plasmid Lactobacillus sake LB790(pSAK20/pSSP2) heterologous expression system described earlier (Axelsson et al., 1998).

The indicator strains used for bacteriocin activity measurements were Lb. sake NCDO 2714 (type strain), Carnobacterium piscicola UI49 (Stoffels et al., 1992) and Enterococcus faecalis NCDO 581 with or without an immunity-genecontaining plasmid. All LAB strains except C. piscicola UI49 were grown in MRS broth (Oxoid) at $30^{\circ} \mathrm{C}$. C. piscicola UI49 was grown in M17 (Oxoid) supplemented with glucose and Tween 80 to final concentrations of $0 \cdot 4 \%(\mathrm{w} / \mathrm{v})$ and $0 \cdot 1 \%$ $(\mathrm{v} / \mathrm{v})$, respectively. Agar plates for Lactobacillus transformants were made by adding $1.5 \%$ agar to MRS broth. Enterococcus and Carnobacterium transformants were grown on BSR agar plates made by adding $1.5 \%(\mathrm{w} / \mathrm{v})$ agar to BSR medium (Holo \& Nes, 1995). Escherichia coli JM109 or Epicurian coli XL-1 Blue (Stratagene) were used for all plasmid cloning. They were grown in Luria-Bertani (LB) medium (Difco) with vigorous agitation at $37^{\circ} \mathrm{C}$. LB agar plates were solidified by adding $1.5 \%(\mathrm{w} / \mathrm{v})$ agar to the LB medium. Selective antibiotic concentrations used were $150 \mu \mathrm{g}$ erythromycin $\mathrm{ml}^{-1}$ and $50 \mu \mathrm{g}$ ampicillin $\mathrm{ml}^{-1}$ for E. coli. For Lb. sake and C. piscicola, the erythromycin concentrations that were used for initial selection and normal growth were 2 and $5 \mu \mathrm{g}$ $\mathrm{ml}^{-1}$, respectively, whereas they were 5 and $10 \mu \mathrm{g} \mathrm{ml}^{-1}$ for Ent. faecalis. pGEM-7Zf $(+$ ) (Promega) was used to clone PCR products and DNA restriction fragments containing immunity genes. The LAB-E. coli shuttle vector pMG36e (van de Guchte et al., 1989) containing the strong constitutive P32 promoter was used to express the immunity genes.

The natural sakacin $\mathrm{P}$ producer used for studying bacteriocin sensitivity was Lb. sake LTH673 (Tichaczek et al., 1994). As described previously, bacteriocin production by this strain depends on the presence of sufficient amounts of a peptide pheromone that induces expression of bacteriocin genes (Brurberg et al., 1997; Eijsink et al., 1996). Cultures with a stable $\mathrm{Bac}^{-}$phenotype were obtained by strong dilution of a $\mathrm{Bac}^{+}$culture in MRS medium, as described previously (Eijsink et al., 1996). For use as a bacteriocin indicator, a $\mathrm{Bac}^{-}$culture of $L b$. sake LTH673 was grown overnight and diluted according to usual practice (see below).

Production, synthesis and purification of the bacteriocins. Curvacin A, enterocin A, enterocin P, leucocin C, sakacin P and pediocin PA-1 were purified to homogeneity from 0.4 or $0 \cdot 8$ l cultures of their producer strains by ammonium sulphate precipitation, followed by cation-exchange chromatography, hydrophobic-interaction chromatography and reverse-phase chromatography, as described previously (Nieto Lozano et al., 1992). Leucocin A was obtained by peptide synthesis, as described previously (Fimland et al., 1996). 
Table 1. Plasmids used in this study

\begin{tabular}{|c|c|c|c|c|c|}
\hline Plasmid & Description & $\begin{array}{c}\text { GenBank } \\
\text { entry }\end{array}$ & $\begin{array}{l}\text { Nucleotides included } \\
\text { in gene fragment }\end{array}$ & $\begin{array}{l}\text { Source of } \\
\text { immunity gene }\end{array}$ & Reference \\
\hline pMG36e & $\begin{array}{l}\mathrm{LAB} / E \text {. coli expression } \\
\text { vector containing } \\
\text { promoter P32, Emr }\end{array}$ & - & - & - & $\begin{array}{l}\text { van de Guchte } \\
\text { et al. (1989) }\end{array}$ \\
\hline pCIM & $\begin{array}{l}\text { pMG36e + curvacin A } \\
\text { immunity }\end{array}$ & Z46867 & $1003-601$ & $\begin{array}{l}\text { Lb. curvatus LTH1174 } \\
\text { (Tichaczek et al., 1993) }\end{array}$ & This study \\
\hline pEAIM & $\begin{array}{l}\text { pMG36e + enterocin A } \\
\text { immunity }\end{array}$ & X94181 & $218-689$ & $\begin{array}{l}\text { Ent. faecium CTC492 } \\
\text { (Aymerich et al., 1996) }\end{array}$ & This study \\
\hline pEPIM & $\begin{array}{l}\text { pMG36e + enterocin P } \\
\text { immunity }\end{array}$ & AF005726 & $320-716$ & $\begin{array}{l}\text { Ent. faecium P13 (Cintas } \\
\text { et al., 1997) }\end{array}$ & This study \\
\hline pLIM & $\begin{array}{l}\text { pMG36e + leucocin A } \\
\text { immunity }\end{array}$ & M64371 & 479-909 & $\begin{array}{l}\text { L. mesenteroides \#6 } \\
\text { (Vaughan } \text { et al., 2001) }\end{array}$ & This study \\
\hline pORFY & pMG36e + ORFY & AF002276 & $1118-1523$ & $\begin{array}{l}\text { Lb. sake LTH673 (Tichaczek } \\
\text { et al., 1994) }\end{array}$ & This study \\
\hline pPIM & $\begin{array}{l}\text { pMG36e + pediocin } \\
\text { immunity }\end{array}$ & M88924 & $1260-1652$ & $\begin{array}{l}\text { P. acidilactici PAC1·0 } \\
\text { (Marugg et al., 1992) }\end{array}$ & This study \\
\hline pSIM & $\begin{array}{l}\text { pMG36e + sakacin } P \\
\text { immunity }\end{array}$ & AF002276 & $4183-4923$ & $\begin{array}{l}\text { Lb. sake LTH673 (Tichaczek } \\
\text { et al., 1994) }\end{array}$ & This study \\
\hline
\end{tabular}

The purity of the isolated bacteriocins was analysed by analytical chromatography on a $\mu$ RPC SC 2.1/10 $\mathrm{C}_{2} \mathrm{C}_{18}$ column (Amersham Biosciences) using the SMART chromatography system (Amersham Biosciences) and water/2-propanol, containing $0 \cdot 1 \%(\mathrm{v} / \mathrm{v})$ trifluoroacetic acid, as the mobile phase. Primary structures were confirmed by mass spectrometry on a Voyager-DE RP matrix-assisted laser desorption time-of-flight mass spectrometer (Perseptive Biosystems); $\alpha$-cyano-4-hydroxycinnamic acid was used as the matrix.

\section{Construction of plasmids containing immunity genes.}

Plasmids containing cloned immunity genes and the sources of these immunity genes are listed in Table 1. PCR fragments containing the curvacin $\mathrm{A}$, enterocin $\mathrm{P}$ or leucocin A immunity genes with flanking EcoRI and BamHI restriction sites were subcloned into pGEM-7Zf $(+$ ) (Promega), whereas a PCR fragment containing orf $\mathrm{Y}$ (with no flanking restriction sites) was cloned into pCR2.1-TOPO (Invitrogen). The subcloned immunity genes were then excised with $\mathrm{SacI}$ and $\mathrm{XbaI}$ (curvacin A, leucocin A, orf Y) or with SacI and PstI (enterocin $\mathrm{P})$ and subcloned into the $\mathrm{SacI}$ and $\mathrm{XbaI}$ or $\mathrm{SacI}$ and PstI sites of pMG36e, respectively. Larger PCR fragments containing both the bacteriocin gene and cognate immunity gene and subcloned into the Bam HI and EcoRI site of pGEM-7Zf $(+)$ (Promega) (unpublished results) were used as a starting point for cloning the immunity genes of pediocin PA-1 and enterocin A. The pediocin PA-1 gene was removed by Bam HI-NheI digestion followed by re-ligation of the remaining plasmid. The immunity gene $(p e d B)$ was then excised from the plasmid by $X b a \mathrm{I}$ and $S a c I$ and subcloned into the $X b a \mathrm{I}$ and $S a c I$ sites of pMG36e. The enterocin A immunity gene was excised from the pGEM-7Zf $(+)$ subclone by $R$ saI and EcoRI digestion and subcloned into the $S m a \mathrm{I}$ and EcoRI sites of pGEM-7Zf $(+)$ (Promega). From this, an $\mathrm{XbaI}-\mathrm{SacI}$ restriction fragment containing the enterocin A immunity gene was subcloned into the $\mathrm{SacI}$ and $\mathrm{XbaI}$ sites of pMG36e. The sakacin P immunity gene was excised from plasmid pPT1000 (Tichaczek et al., 1994) using PvuII and subcloned into the SmaI site of pGEM-
$7 \mathrm{Zf}(+)$ (Promega). A HindIII-XbaI fragment from this construct was then isolated and subcloned into the HindIII and $\mathrm{XbaI}$ sites of pMG36e.

Plasmid isolation and transformation. All plasmid isolations from both E. coli and LAB were done using the Wizard Plus SV Minipreps DNA Purification System (Promega). Lysis of LAB strains was performed by adding lysozyme and mutanolysin to the Cell Resuspension Solution (Promega) to final concentrations of $5 \mathrm{mg} \mathrm{ml}^{-1}$ and $15 \mathrm{U} \mathrm{ml}^{-1}$, respectively. The Bio-Rad gene pulser was used for all electroporations. E. coli XL-1 Blue supercompetent cells were transformed according to the protocol provided by the producer (Stratagene). E. coli JM109 was made electrocompetent and transformed as described previously (Dower et al., 1988). Lb. sake was made electrocompetent and transformed as described in Aukrust et al. (1995). After growth from $\mathrm{OD}_{610} 0 \cdot 1$ to $\mathrm{OD}_{610} 0.6$ in the presence of $2 \%(\mathrm{w} / \mathrm{v})$ glycine, the cells were washed in $1 \mathrm{mM}$ $\mathrm{MgCl}_{2}$ followed by a wash in $30 \%$ (w/v) polyethylene glycol 1500 (molecular mass range 1300-1600) prior to electroporation. C. piscicola UI49 was made electrocompetent and transformed according to a method developed for Lactococcus strains (Holo \& Nes, 1995). C. piscicola was grown in GM17 overnight in the presence of $2 \%(\mathrm{w} / \mathrm{v})$ glycine and washed twice in $0.5 \mathrm{M}$ sucrose solution containing $10 \%(\mathrm{v} / \mathrm{v})$ glycerol. Electrocompetent Ent. faecalis were produced by growing them overnight in M17 containing $7 \%$ (w/v) glycine and $0.5 \mathrm{M}$ sucrose at $37^{\circ} \mathrm{C}$. The cells were thereafter washed twice in $0.5 \mathrm{M}$ sucrose containing $10 \%(\mathrm{v} / \mathrm{v})$ glycerol (Shepard \& Gilmore, 1995).

Polymerase chain reaction and DNA sequencing. Eurogentec, Belgium, produced all oligo primers used in this study. The immunity genes were amplified by PCR using a standard amplification protocol on a GeneAmp PCR System 2400 (Perkin Elmer) using a PfuTurbo DNA polymerase (Stratagene). PCR mixtures contained $50 \mathrm{ng}$ plasmid DNA or $1-5 \mu \mathrm{l}$ DNA preparations with unknown concentrations made from the bacteriocin producers (Table 1), 125 ng each primer, dNTP (Amersham Biosciences) to a final concentration of 
$0.05 \mathrm{mM}$ of each nucleotide, $10 \times$ reaction buffer (Stratagene) and 2.5 U PfuTurbo DNA polymerase (Stratagene). Amplification proceeded through 25 cycles after a 3 min hot start at $95^{\circ} \mathrm{C}$ with a programme including denaturation $(1 \mathrm{~min}$ at $\left.95^{\circ} \mathrm{C}\right)$, primer annealing $\left(1 \mathrm{~min}\right.$ at $\left.50^{\circ} \mathrm{C}\right)$ and polymerization $\left(1 \mathrm{~min}\right.$ at $\left.68^{\circ} \mathrm{C}\right)$.

The DNA sequences of the cloned immunity genes were verified by automated DNA sequence determination, using an ABI PRISM 377 DNA sequencer and the ABI Prism Ready Reaction dye terminator cycle sequencing kit (Perkin Elmer).

Bacteriocin assay. Bacteriocin activity was measured by using a microtitre plate assay system, essentially as described previously (Nissen-Meyer et al., 1992). Each well of a microtitre plate contained $200 \mu$ l of culture medium with bacteriocin fractions at twofold dilutions and an indicator strain at an $\mathrm{OD}_{610}$ of about $0 \cdot 01$ (inoculated from a $16-20 \mathrm{~h}$ overnight culture at $30^{\circ} \mathrm{C}$ ). The microtitre plate cultures were incubated overnight $(14-16 \mathrm{~h})$, at $30^{\circ} \mathrm{C}$, after which growth of the indicator strain was measured spectrophotometrically at $610 \mathrm{~nm}$ with a microtitre plate reader. The MIC was defined as the concentration of bacteriocin that inhibited growth of the indicator strain by $50 \%$. The MIC values that are presented are the result of at least three independent measurements and had standard deviations of less than $50 \%$ of the value. Transformed indicator strains were grown in the presence of $5 \mu \mathrm{g}$ erythromycin $\mathrm{ml}^{-1}$ to ensure that the plasmid containing the immunity gene was maintained in the cells. The protection pattern of each immunity protein was judged by comparing MIC values for a strain expressing an immunity gene with MIC values for the same strain containing the unmodified pMG36e plasmid. Control experiments showed that neither the presence of erythromycin nor the presence of plasmid pMG36e influenced the bacteriocin sensitivity of the indicator cells.

Biocomputational analysis. The PILEUP program of the Genetics Computer Group sequence analysis program package (Wisconsin Package Version 8.1, Genetics Computer Group) was used to create phylogenetic trees to reveal evolutionary relationships between immunity proteins and their corresponding bacteriocins. The same program was used to set up multiple sequence alignments of immunity proteins and bacteriocins. The gap-creation and gap-extension penalties were set to $3 \cdot 00$ and $0 \cdot 10$, respectively. Protein sequences were taken from the Swissprot database or obtained by in computo translation of the corresponding DNA sequences as present in GenBank.

\section{RESULTS AND DISCUSSION}

\section{Pediocin-like bacteriocins and their immunity proteins may be subclassified on the basis of sequence similarities}

In contrast to the well-conserved $\mathrm{N}$-terminal parts, the C-terminal parts of pediocin-like bacteriocins show enough sequence diversity to enable subgrouping of most of these bacteriocins (Fig. 1). Bacteriocins within a group display sequence characteristics in their Cterminal halves that are not pronounced in bacteriocins that belong to another group.

Structural studies of pediocin-like bacteriocins (Fregeau Gallagher et al., 1997; H. H. Hauge, personal communication; Wang et al., 1999) suggest that these

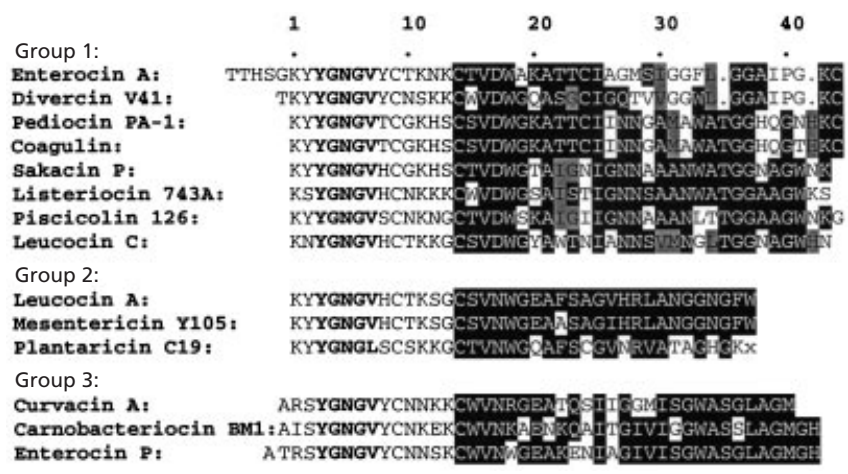

Fig. 1. Sequence alignment and grouping of pediocin-like bacteriocins. Group 1: enterocin A (Aymerich et al., 1996), divercin V41 (Métivier et al., 1998), pediocin PA-1 (Marugg et al., 1992), coagulin (Le Marrec et al., 2000), sakacin P (Tichaczek et al., 1994), listeriocin 743A (Kalmokoff et al., 2001), piscicolin 126 (Jack et al., 1996) and leucocin C (Fimland et al., 2002b; Vaughan et al., 2001). Group 2: leucocin A (Hastings et al., 1991), mesentericin Y105 (Fremaux et al., 1995) and plantaricin C19 (Atrih et al., 2001). Group 3: curvacin A (Tichaczek et al., 1993), carnobacteriocin BM1 (Quadri et al., 1994) and enterocin $P$ (Cintas et al., 1997). The bacteriocins were grouped on the basis of sequence similarities in their C-terminal regions. Conserved amino acids in these regions are marked with black and grey boxes. The following amino acids were considered similar: $\mathrm{D}$ and $\mathrm{E} ; \mathrm{F}$ and $\mathrm{Y} ; \mathrm{I}, \mathrm{V}$ and $\mathrm{L} ; \mathrm{N}$ and $\mathrm{Q} ; \mathrm{K}$ and $\mathrm{R} ; \mathrm{S}$ and $\mathrm{T}$. It is known from previous studies (e.g. Eijsink et al., 1998; Fimland et al., 2000) that the cysteines in positions 9 and 14 form a disulphide bridge. The upper four bacteriocins in group 1 have a second, 'C-terminal' disulphide bridge involving residues 24 and 44 .

peptides are helical in a region containing 15-22 residues and starting closely after the fully conserved Cys14 (Fig. 1). The C-terminal six to 10 residues were found to have little structure. In some of the group 1 bacteriocins, the presumably flexible C-terminal end of the peptide is stabilized by a C-terminal disulphide bridge between a C-terminal cysteine (Cys44 in pediocin PA-1) and a cysteine (Cys24) in the putative helical part of the peptide (Fimland et al., 2000; Watson et al., 2001). In group 1 bacteriocins that lack this disulphide bridge, an extra tryptophan residue at position 41 apparently makes a similar contribution to bacteriocin stability and activity (Fimland et al., 2002a). Bacteriocins in group 2 are clearly shorter than group 1 bacteriocins, meaning that either their helical parts or their flexible C-terminal ends must be shorter than in bacteriocins belonging to group 1. Bacteriocins in group 3 are of a similar length to those in group 1, but they show quite different sequences, and they lack both the C-terminal disulphide bridge and the tryptophan residue near the C-terminal end (Fig. 1).

Despite high sequence similarities among pediocin-like bacteriocins (Fig. 1), most of their immunity proteins show little similarity. Nevertheless, it is possible to identify some common sequence motifs, and by combining multiple sequence alignments and phylogenetic analyses (results not shown), three subgroups became 


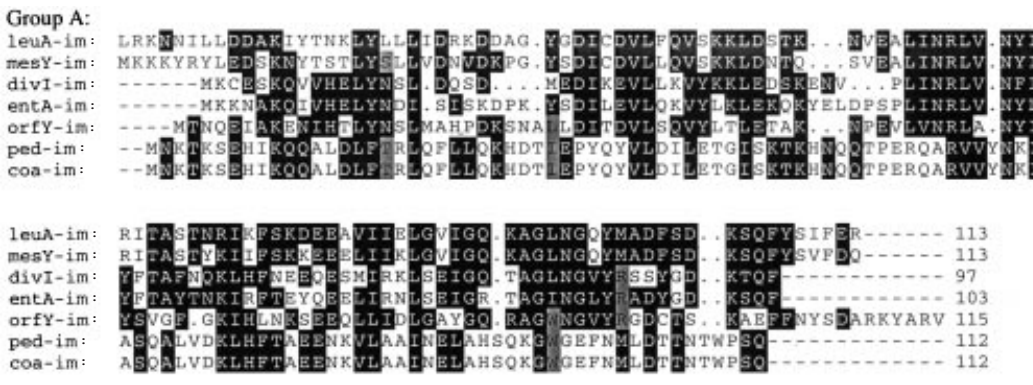

Fig. 2. Sequence alignment and grouping of putative immunity proteins of pediocin-like bacteriocins. Regions of sequence similarity are indicated by black and grey boxes. The following amino acids were considered similar: $\mathrm{D}$ and $\mathrm{E} ; \mathrm{F}$ and $\mathrm{Y} ; \mathrm{I}, \mathrm{V}$ and $\mathrm{L} ; \mathrm{N}$ and $\mathrm{Q} ; \mathrm{K}$ and $\mathrm{R} ; \mathrm{S}$ and $\mathrm{T}$. Group A consists of the following (putative) immunity proteins: leucocin A (leuA-im), mesentericin Y105 (mesY-im), divercin V41 (divl-im), enterocin A (entA-im), ORF in sakacin $P$ locus, no corresponding bacteriocin (orfY-im), pediocin PA-1 (ped-im) and coagulin (coaim). Group B consists of the following (putative) immunity proteins: ORF in the carnobacteriocin locus, no corresponding bacteriocin (orf $\beta 3$ ), piscicolin 126 (pisc-im), sakacin P (sakP-im), listeriocin 743A (lisA-im) and ORF in the divercin V41 locus, no corresponding bacteriocin (divT2-im). Group C consists of the following (putative) immunity proteins: carnobacteriocin B1 (cbnBM1-im), curvacin A (curA-im), enterocin P (entP-im). See text for references.

apparent (Fig. 2). Group A contains the immunity proteins for bacteriocins that belong to group 2 and the four group 1 bacteriocins (enterocin A, divercin V41, pediocin PA-1 and coagulin) that contain a C-terminal disulphide bridge. Group A also contains the putative immunity protein orf-Y that lacks a cognate bacteriocin. Group B contains the immunity proteins for the group 1 bacteriocins that lack the C-terminal disulphide bridge and two putative immunity proteins (orf- $\beta 3$ and divT2) that lack cognate bacteriocins. Group $\mathrm{C}$ contains the immunity proteins for group 3 bacteriocins.

\section{Immunity proteins display specificity and cross- immunity}

The close sequence similarities between pediocin-like bacteriocins suggest that their immunity proteins might protect against several bacteriocins in addition to their cognate bacteriocin. However, the much lower sequence similarities between immunity proteins suggest that the immunity proteins might display a high degree of specificity. To determine the specificity of the immunity proteins, seven different immunity genes were expressed in bacteriocin-sensitive Lb. sake NCDO 2714, C. piscicola UI49 and Ent. faecalis NCDO 581, and the sensitivity of the transformed bacteria to different bacteriocins was then tested. To account for possible variations in group $\mathrm{A}$ (which contains immunity proteins belonging to two subgroups of bacteriocins), four of the seven immunity genes were chosen from this group. The genes from group A were ped-im and entA-im, whose cognate bacteriocins belong to group 1, leuA-im, whose cognate bacteriocin belongs to group 2, and orf Y, which lacks a cognate bacteriocin. From group B, the sakP-im gene was chosen, whereas the curA-im and entP-im genes were chosen from group C. The bacteriocin sensitivity of target cells overexpressing immunity genes was assessed using two group 1 bacteriocins containing a C-terminal disulphide bridge (enterocin $\mathrm{A}$ and pediocin PA-1), two group 1 bacteriocins not containing this bridge (sakacin $\mathrm{P}$ and leucocin $\mathrm{C}$ ), one group 2 bacteriocin (leucocin A) and two group 3 bacteriocins (curvacin $\mathrm{A}$ and enterocin $\mathrm{P}$ ).

All transformed indicator strains displayed immunity to the bacteriocin belonging to the cloned immunity gene (Table 2), showing that the immunity genes indeed were expressed. They also displayed immunity to several other bacteriocins ('cross-immunity'). With a few exceptions, these other bacteriocins belonged to the same group as the cognate bacteriocin. For example, the group $\mathrm{C}$ immunity proteins curA-im and entP-im both protected against group 3 bacteriocins curvacin $\mathrm{A}$ and enterocin $\mathrm{P}$, but none of them yielded immunity to bacteriocins belonging to group 1 or 2 (Table 2). Similarly, both ped-im and sakP-im protected cells against group 1 bacteriocins, pediocin PA-1, sakacin P and leucocin C, but not against any of the group 2 and 3 bacteriocins that were tested (Table 2).

In a very few cases, (marginal) cross-immunity was observed for bacteriocins belonging to different groups. In all these cases, the immunity proteins of the cognate and non-cognate bacteriocins belonged to the same group. For example, leuA-im, which is in the same group (A) as entA-im and ped-im, gave immunity to group 1 bacteriocins enterocin A and pediocin PA-1 in 
Table 2. Bacteriocin sensitivity of strains expressing various immunity genes

The results are presented as the increase in MIC value observed in strains expressing an immunity gene, relative to strains only containing the control plasmid (pMG36e). - , <2·5-fold increase; $(-), 2 \cdot 6-3 \cdot 9$-fold increase; $(+), 4 \cdot 0-7 \cdot 9$-fold increase; +, $>8$-fold increase. The three symbols in each cell represent the three different indicator strains used in this study, from left to right: $L$. sake NCDO 2714, C. piscicola UI49, Ent. faecalis NCDO 581. Letters and numbers in parentheses refer to the group to which the immunity protein or bacteriocin belongs.

\begin{tabular}{|c|c|c|c|c|c|c|c|}
\hline \multirow{2}{*}{$\begin{array}{l}\text { Immunity } \\
\text { protein }\end{array}$} & \multicolumn{7}{|c|}{ Bacteriocin } \\
\hline & $\begin{array}{c}\text { Curvacin A } \\
(3)\end{array}$ & $\begin{array}{c}\text { Enterocin P } \\
(3)\end{array}$ & $\begin{array}{c}\text { Enterocin A } \\
\text { (1) }\end{array}$ & $\begin{array}{c}\text { Leucocin A } \\
(2)\end{array}$ & $\begin{array}{c}\text { Pediocin PA-1 } \\
(1)\end{array}$ & $\begin{array}{c}\text { Sakacin P } \\
(1)\end{array}$ & $\begin{array}{c}\text { Leucocin C } \\
(\mathbf{1})\end{array}$ \\
\hline curA-im $(\mathrm{C})$ & $(+)(+)+$ & +++ & --- & --- & --- & --- & --- \\
\hline entP-im (C) & $(-)-(+)$ & +++ & --- & --- & --- & --- & --- \\
\hline ped-im (A) & --- & --- & --- & --- & +++ & +++ & +++ \\
\hline sakP-im (B) & --- & --- & --- & --- & +++ & +++ & +++ \\
\hline entA-im (A) & --- & --- & +++ & $--(-)$ & --- & $(-)(+)+$ & $++(+)$ \\
\hline leuA-im (A) & --- & --- & --+ & $+(+)+$ & --+ & --- & --- \\
\hline orfY-im (A) & $--(+)$ & --- & +++ & +++ & $(-)--$ & --- & --- \\
\hline
\end{tabular}

one of the indicator strains, whereas its cognate bacteriocin belongs to group 2. Similarly, entA-im (cognate bacteriocin in group 1) protected one of the strains slightly against the group 2 bacteriocin leucocin A, whose immunity gene belongs to the same group as entA-im (group A).

The general picture emerging from the results displayed in Table 2 is that the immunity proteins display a significant degree of specificity. Thus, despite the strong sequence similarities between pediocin-like bacteriocins (especially in the $\mathrm{N}$-terminal part), none of the immunity proteins tested comes close to providing 'general immunity' towards this class of antimicrobial peptides. From the data in Table 2, one might conclude, though, that certain (sequence-based) subgroups of immunity proteins have a tendency to provide immunity to certain groups of bacteriocins that are characterized by similarities in their C-terminal parts. It is important to note that exceptions do exist that limit the applicability and predictive power of subgrouping bacteriocins and/or immunity proteins. For example, whereas sakP-im (B) and ped-im (A) both provide immunity to group 1 bacteriocins pediocin PA-1, sakacin P and leucocin C, they do not provide immunity to the group 1 bacteriocin enterocin A.

\section{Immunity protein functionality is strain-dependent}

The data in Table 2 show that the effectiveness of some of the overexpressed immunity proteins is strain-dependent. Obviously, parts of the observed straindependent differences may relate to different expression levels of the immunity proteins. However, the data do contain a few examples where such differences in expression levels are likely not to exist. For example, entA-im provides maximal immunity towards enterocin A and leucocin C in Lb. sake NCDO 2714 and in C. piscicola UI49, whereas it provides immunity towards enterocin A and sakacin P in Ent. faecalis NCDO 581. This shows that the gene is expressed in all three strains, but the strains obtain rather different degrees of immunity. Another example: in Ent. faecalis, leuA-im provides maximum immunity towards enterocin A, leucocin A and pediocin PA-1; in Lb. sake, the gene is also expressed, as shown by immunity to leucocin $\mathrm{A}$, but immunity to enterocin A and pedicion PA-1 is not observed. Taken together, the results in Table 2 strongly indicate that immunity protein functionality in part depends on interplay with strain-dependent factors.

\section{The putative immunity gene orfY encodes a protein that provides immunity to several pediocin-like bacteriocins}

It is known from previous studies that putative immunity genes for which a cognate bacteriocin has not been identified may be expressed, e.g. orf- $\beta 3$ in bacteriocin-producing C. piscicola LV17B (Quadri et al., 1994). The orf $Y$ gene in the sakacin $\mathrm{P}$ producer $L b$. sake LTH673 (Brurberg et al., 1997) is expressed at low levels in bacteriocin-producing cells only, yielding a transcript whose length indicates that it contains only orf $Y(\mathrm{M}$. B. Brurberg \& V. G. H. Eijsink, unpublished observations; Eijsink et al., 1998).

The present results clearly show that orf $Y$ indeed is an immunity gene, as its overexpression made all three indicator strains immune to enterocin A and leucocin A. Overexpression of orf $Y$ also protected the Enterococcus strain against curvacin A (Table 2). Interestingly, orf $Y$ $i m$ and sakP-im complement each other in the sense that they protect cells against different bacteriocins (Table 2). Thus, sakacin P-producing Lb. sake LTH673 has at least two functional immunity genes, sakP-im and orf Y$\mathrm{im}$, and should be immune to a broader spectrum of 
Table 3. Bacteriocin sensitivity of bacteriocin producers

\begin{tabular}{|c|c|c|c|c|c|c|c|c|}
\hline \multirow[t]{2}{*}{ Indicator strain* } & \multirow{2}{*}{$\begin{array}{c}\text { Bacteriocin } \\
\text { produced }\end{array}$} & \multirow{2}{*}{$\begin{array}{l}\text { Known immunity } \\
\text { genes }\end{array}$} & \multicolumn{6}{|c|}{ MIC (nM) of bacteriocin: } \\
\hline & & & $\begin{array}{c}\text { Curvacin } \\
\text { A }\end{array}$ & $\begin{array}{c}\text { Enterocin } \\
\mathbf{P}\end{array}$ & $\begin{array}{c}\text { Enterocin } \\
\text { A }\end{array}$ & $\begin{array}{c}\text { Leucocin } \\
\text { A }\end{array}$ & $\begin{array}{l}\text { Pediocin } \\
\text { PA-1 }\end{array}$ & $\begin{array}{c}\text { Sakacin } \\
\text { P }\end{array}$ \\
\hline Lb. curvatus LTH1174 & Curvacin A & curA-im & $>70$ & $>60$ & 15 & 15 & 28 & 30 \\
\hline Ent. faecium $\mathrm{P} 13$ & Enterocin $\mathrm{P}$ & entP-im & 320 & 900 & $0 \cdot 05$ & $0 \cdot 1$ & $0 \cdot 03$ & $0 \cdot 27$ \\
\hline Lb. sake LTH673 $\mathrm{Bac}^{-}$ & None & sakP-im, orfY-im & $3 \cdot 5$ & 25 & $0 \cdot 45$ & $0 \cdot 43$ & $1 \cdot 8$ & $7 \cdot 2$ \\
\hline Lb. sake LTH673 $\mathrm{Bac}^{+}$ & Sakacin P & sakP-im, orfY-im & 40 & 100 & $3 \cdot 2$ & $1 \cdot 3$ & $>100$ & $>100$ \\
\hline P. acidilactici LMG2351 & Pediocin PA-1 & ped-im & $>100$ & $>100$ & $>100$ & $>100$ & $>100$ & $>100$ \\
\hline
\end{tabular}

$* \mathrm{Bac}^{-}$and $\mathrm{Bac}^{+}$refer to the non-producing and producing state, respectively (see Methods for details).

bacteriocins than if only the sakP-im gene had been present (see below).

\section{Bacteriocin sensitivity of bacteriocin-producing strains}

Bacteriocin-producing strains contain one or more known immunity genes and are thus expected to be immune to the bacteriocins identified by the heterologous expression studies described above. Table 3 shows that this is indeed the case for the curvacin A producer, Lb. curvatus LTH1174, and the enterocin P producer, Ent. faecium P13, which are known to contain curA-im and entP-im, respectively. Both strains were much more resistant to curvacin $\mathrm{A}$ and enterocin $\mathrm{P}$ than to the other bacteriocins tested, in accordance with the results obtained upon heterologous expression of the corresponding immunity genes curA-im and entP-im (Table 2). It is interesting to note that there is a considerable general difference in bacteriocin sensitivity between the two producer strains.

Production of sakacin P by Lb. sake LTH673 is regulated by quorum sensing (Brurberg et al., 1997). This strain can be made to enter a non-producing $\left(\mathrm{Bac}^{-}\right)$state, and immunity can then be shut off due to transcriptional coupling between the bacteriocin and immunity genes (Eijsink et al., 1996). Table 3 shows that Lb. sake LTH673 indeed was much more sensitive to various pediocin-like bacteriocins in the $\mathrm{Bac}^{-}$state than in the $\mathrm{Bac}^{+}$state. For example, in the $\mathrm{Bac}^{-}$state, the strain was highly sensitive to both sakacin $\mathrm{P}$ and pediocin PA-1, bacteriocins to which it is normally immune, presumably because of expression of sakP-im (Table 2). Interestingly, activation of bacteriocin gene expression in Lb. sake LTH673 gave a clear increase in immunity to curvacin $\mathrm{A}$, enterocin $\mathrm{A}$, enterocin $\mathrm{P}$ and leucocin $\mathrm{A}$, which cannot be readily explained by cross-immunity provided by sakP-im, but which can be largely explained by low production of orfY-im (Table 2).

The pediocin PA-1 producer $P$. acidilactici LMG2351 was immune to all bacteriocins tested; that is, it was much more immune than could be expected on the basis of heterologous expression studies with its one known immunity gene, ped-im (Table 2). Thus, either this strain must possess and express other functional immunity genes, or its physiological state must be such that it has generally reduced sensitivity ('resistance') for pediocin-like bacteriocins (see below for further discussion).

\section{Concluding remarks}

The subgrouping of pediocin-like bacteriocins on the basis of the amino acid sequences of their C-terminal halves (Fig. 1) may be open for debate and may need adjustments as more bacteriocin sequences become known. Nevertheless, the present results strongly suggest that the extent to which an immunity protein interacts (directly or indirectly) with a bacteriocin depends to a significant extent on the C-terminal part of the latter. The C-terminal part is also the region that interacts with the hydrophobic part of the membrane (Fimland et al., 1996, 2000, 2002a; Miller et al., 1998), which suggests that immunity proteins and bacteriocins directly or indirectly interact in this part of the membrane.

A major question is whether immunity proteins have direct interactions with bacteriocins or whether immunity is based on a more indirect effect, e.g. the blocking of receptors. Despite the fact that, so far, it has not been possible to demonstrate direct bacteriocinimmunity protein interactions (Quadri et al., 1995), the existence of such interactions cannot be excluded. For example, it is possible that the immunity protein and the bacteriocin interact only after the bacteriocin has become membrane-bound and structured (pediocin-like bacteriocins are largely unstructured in aqueous solutions but become structured in the presence of liposomes, for example; Fregeau Gallagher et al., 1997; Wang et al., 1999; Watson et al., 2001). Interactions occurring in or near a membrane are difficult to reproduce in vitro and may therefore so far have remained undetected. The recent discovery that a membrane-bound protein that is part of a mannose phosphotransferase system permease (EII ${ }^{\text {Man }}$ ) is involved in sensitivity of Listeria monocytogenes and Ent. faecalis towards pediocin-like bacteriocins (Dalet et al., 2001; Héchard et al., 2001; Ramnath et al., 2000) opens up 
new perspectives. It is likely that this protein is the long sought-after 'receptor' or 'docking molecule' for at least some pediocin-like bacteriocins (Dalet et al., 2001). Immunity proteins (located in the cytoplasm) may act by binding to the cytoplasmic side of this receptor, which somehow could block the receptor's ability to interact with the bacteriocin in a fashion that is necessary for bacteriocin action.

Our results do not provide conclusive evidence for resolving this issue. Sequence variations in the immunity proteins and the $\mathrm{C}$-terminal parts of the bacteriocins can in principle account for differences in immunity protein functionality in each of these models. The receptor model is attractive, not least in view of early work by Venema et al. (1994), which suggests that immunity towards the non-pediocin-like class II bacteriocin lactococcin A is mediated by a receptor. The fact that there is some strain-dependent variation in immunity protein functionality is consistent with the view that immunity is mediated via interactions with a specific proteinaceous receptor (e.g. EII ${ }^{\text {Man }}$ ), since the receptor protein is likely to vary between the indicator strains (which belong to three different genera). However, one might expect a much larger strain-dependent variation if immunity really were mediated by such a receptor. Clearly, more work needs to be done, combining the strategies described here with the strategies used in the work on the permease receptors (Dalet et al., 2001; Héchard et al., 2001). The relatively high specificity of immunity proteins found in this study does already yield one important conclusion: it is quite unlikely that an immunity protein-receptor complex still functions as a receptor for some bacteriocins but no longer for others. Thus, if the immunity proteins tested in this study act by blocking a receptor, there must be several receptors for pediocin-like bacteriocins, only some of which are blocked by a particular immunity protein.

It is well known that closely related LAB may differ strongly in terms of bacteriocin sensitivity. Variation in bacteriocin sensitivity depends in part on 'general' inter-strain differences such as membrane composition and the presence of receptors (Crandal \& Montville, 1998; Ennahar et al., 2000). The present results indicate that the presence, expression and functionality of immunity proteins are also significant, if not major, factors in determining bacteriocin sensitivity of closely related LAB. First, immunity proteins that are directly related to a strain's own bacteriocin production provide varying degrees of cross-immunity. Second, strains may contain genes that are expressed and code for functional immunity proteins but that lack cognate bacteriocins (e.g. $\operatorname{orf} Y$ ). As shown above, the functionality of some of these immunity proteins may be strain-dependent, providing an additional cause of variation in bacteriocin sensitivity.

The fact that the C-terminal part of bacteriocins plays a major role in determining target cell specificity (Fimland et al., 1996, 2000) and in the (direct or indirect) interaction with immunity proteins may be taken to support the notion that immunity proteins play a major role in determining bacteriocin sensitivity. If immunity proteins that lack cognate bacteriocins are widely spread in target bacteria, the (direct or indirect) interaction of these proteins with the C-terminal part of the bacteriocins may be one mechanism by which this C-terminal part is involved in determining the target-cell specificity.

\section{ACKNOWLEDGEMENTS}

This work was supported by a grant from the Norwegian Research Council.

\section{REFERENCES}

Atrih, A., Rekhif, N., Moir, A. J., Lebrihi, A. \& Lefebvre, G. (2001). Mode of action, purification and amino acid sequence of plantaricin C19, an anti-Listeria bacteriocin produced by Lactobacillus plantarum C19. Int J Food Microbiol 68, 93-104.

Aukrust, T. W., Brurberg, M. B. \& Nes, I. F. (1995). Transformation of Lactobacillus by electroporation. In Methods in Molecular Biology, vol. 47, Electroporation Protocols for Microorganisms, pp. 201-208. Edited by J. A. Nickoloff. Totowa, NJ: Humana Press.

Axelsson, L. \& Holck, A. (1995). The genes involved in production of and immunity to sakacin A, a bacteriocin from Lactobacillus sake Lb706. J Bacteriol 177, 2125-2137.

Axelsson, L., Katla, T., Bjørnslett, M., Eijsink, V. G. H. \& Holck, A. (1998). A system for heterologous expression of bacteriocins in Lactobacillus sake. FEMS Microbiol Lett 168, 137-143.

Aymerich, T., Holo, H., Håvarstein, L. S., Hugas, M., Garriga, M. \& Nes, I. F. (1996). Biochemical and genetic characterization of enterocin A from Enterococcus faecium, a new antilisterial bacteriocin in the pediocin family of bacteriocins. Appl Environ Microbiol 62, 1676-1682.

Brurberg, M. B., Nes, I. F. \& Eijsink, V. G. H. (1997). Pheromoneinduced production of antimicrobial peptides in Lactobacillus. Mol Microbiol 26, 347-360.

Chikindas, M. L., Garcia-Garcera, M. J., Driessen, A. J. M., Ledeboer, A. M., Nissen-Meyer, J., Nes, I. F., Abee, T., Konings, W. N. \& Venema, G. (1993). Pediocin PA-1, a bacteriocin from Pediococcus acidilactici PAC1.0, forms hydrophilic pores in the cytoplasmic membrane of target cells. Appl Environ Microbiol 59, 3577-3584.

Cintas, L. M., Casaus, P., Håvarstein, L. S., Hernández, P. E. \& Nes, I. F. (1997). Biochemical and genetical characterization of enterocin P, a novel sec-dependent bacteriocin from Enterococcus faecium P13 with a broad antimicrobial spectrum. Appl Environ Microbiol 63, 4321-4330.

Crandal, A. D. \& Montville, T. (1998). Nisin resistance in Listeria monocytogenes ATCC700302 is a complex phenotype. Appl Environ Microbiol 64, 231-237.

Dalet, K., Briand, C., Cenatiempo, Y. \& Héchard, Y. (2000). The rpoN gene of Enterococcus faecalis directs sensitivity to subclass IIa bacteriocins. Curr Microbiol 41, 441-443.

Dalet, K., Cenatiempo, Y., Cossart, P., The European Listeria Genome Consortium \& Héchard, Y. (2001). A $\sigma^{54}$-dependent PTS permease of the mannose family is responsible for sensitivity of Listeria monocytogenes to mesentericin Y105. Microbiology 147, 3263-3269.

Dayem, M. A., Fleury, Y., Devilliers, G., Chaboisseau, E., Girard, R., Nicolas, P. \& Delfor, A. (1996). The putative immunity protein 
of the Gram-positive bacterium Leuconostoc mesenteroides is preferentially located in the cytoplasm compartment. FEMS Microbiol Lett 138, 251-259.

Dower, D. J., Miller, J. F. \& Ragsdale, C. W. (1998). High efficiency transformation of Escherichia coli by high voltage electroporation. Nucleic Acids Res 16, 6127-6145.

Eijsink, V. G. H., Brurberg, M. B., Midelhoven, P. J. \& Nes, I. F. (1996). Induction of bacteriocin production in Lactobacillus sake by a secreted peptide. J Bacteriol 178, 2232-2237.

Eijsink, V. G. H., Skeie, M., Middelhoven, H., Brurberg, M. B. \& Nes, I. F. (1998). Comparative studies of pediocin-like bacteriocins. Appl Environ Microbiol 64, 3275-3281.

Ennahar, S., Sashihara, T., Sonomoto, K. \& Ishizaki, A. (2000). Class IIa bacteriocins: biosynthesis, structure and activity. FEMS Microbiol Rev 24, 85-106.

Fimland, G., Blingsmo, O. R., Sletten, K., Jung, G., Nes, I. F. \& Nissen-Meyer, J. (1996). New biologically active hybrid bacteriocins constructed by combining regions from various pediocin-like bacteriocins: the C-terminal region is important for determining specificity. Appl Environ Microbiol 62, 3313-3318.

Fimland, G., Johnsen, L., Axelsson, L., Brurberg, M. B., Nes, I. F., Eijsink, V. G. H. \& Nissen-Meyer, J. (2000). A C-terminal disulfide bridge in pediocin-like bacteriocins renders bacteriocin activity less temperature dependent and is a major determinant of the antimicrobial spectrum. J Bacteriol 182, 2643-2648.

Fimland, G., Eijsink, V. G. H. \& Nissen-Meyer, J. (2002a). Mutational analysis of the role of tryptophan residues in the antimicrobial peptide sakacin P. Biochemistry 41, 9508-9515.

Fimland, G., Sletten, K. \& Nissen-Meyer, J. (2002b). The complete amino acid sequence of the pediocin-like antimicrobial peptide leucocin C. Biochem Biophys Res Commun 295, 826-827.

Fregeau Gallagher, N. L., Sailer, M., Niemczura, W. P., Nakashima, T. T., Stiles, M. E. \& Vederas, J. C. (1997). Three-dimensional structure of leucocin A in trifluoroethanol and dodecylphosphocholine micelles: Spatial location of residues critical for biological activity in type IIa bacteriocins from lactic acid bacteria. Biochemistry 36, 15062-15072.

Fremaux, C., Héchard, Y. \& Cenatiempo, Y. (1995). Mesentericin Y105 gene clusters in Leuconostoc mesenteroides Y105. Microbiology 141, 1637-1645.

Hastings, J. W., Sailer, M., Johnson, K., Roy, K. L., Vederas, J. C. \& Stiles, M. (1991). Characterization of leucocin A-UAL 187 and cloning of the bacteriocin gene from Leuconostoc gelidium. J Bacteriol 173, 7491-7500.

Héchard, Y., Pelletier, C., Cenatiempo, Y. \& Frère, J. (2001). Analysis of $\sigma^{54}$-dependent genes in Enterococcus faecalis: a mannose PTS permease (EII ${ }^{\mathrm{man}}$ ) is involved in sensitivity to a bacteriocin, mesentericin Y105. Microbiology 147, 1575-1580.

Holo, H. \& Nes, I. F. (1995). Transformation of Lactococcus by electroporation. In Methods in Molecular Biology, vol. 47, Electroporation Protocols for Microorganisms, pp. 195-199. Edited by J. A. Nickoloff. Totowa, NJ: Humana Press.

Hühne, K., Axelsson, L., Holck, A. \& Kröckel, L. (1996). Analysis of the sakacin P gene cluster from Lactobacillus sake Lb674 and its expression in sakacin-negative Lb. sake strains. Microbiology 142, 1437-1448.

Jack, R. W., Wan, J., Gordon, J., Harmark, K., Davidson, B. E., Hillier, A. J., Wettenhall, R. E. H., Hickey, M. W. \& Coventry, M. J. (1996). Characterization of the chemical and antimicrobial properties of piscicolin 126, a bacteriocin produced by Carnobacterium piscicola JG126. Appl Environ Microbiol 62, 28972903.
Kalmokoff, M. L., Banerjee, S. K., Cyr, T., Hefford, M. A. \& Gleeson, T. (2001). Identification of a new plasmid-encoded secdependent bacteriocin produced by Listeria innocua 743. Appl Environ Microbiol 67, 4041-4047.

Le Marrec, C., Hyronimus, B., Bressollier, P., Verneuil, B. \& Urdaci, M. C. (2000). Biochemical and genetic characterization of coagulin, a new antilisterial bacteriocin in the pediocin family of bacteriocins, produced by Bacillus coagulans $\mathrm{I}_{4}$. Appl Environ Microbiol 66, 5213-5220.

Marugg, J. D., Gonzalez, C. F., Kunka, B. S., Lederboer, A. M., Pucci, M. J., Toonen, M. Y., Walker, S. A., Zoetmulder, L. C. M. \& Vandenbergh, P. A. (1992). Cloning, expression, and nucleotide sequence of genes involved in production of pediocin PA-1, a bacteriocin from Pediococcus acidilactici PAC1.0. Appl Environ Microbiol 58, 2360-2367.

Métivier, A., Pilet, M.-F., Dousset, X., Sorokine, O., Anglade, P., Zagorec, M., Piard, J.-C., Marion, D., Cenatiempo, Y. \& Fremaux, C. (1998). Divercin V41, a new bacteriocin with two disulphide bonds produced by Carnobacterium divergens V41: primary structure and genomic organization. Microbiology 144, 28372844.

Miller, K. W., Schamber, R., Osmanagaoglu, O. \& Ray, B. (1998). Isolation and characterization of pediocin $\mathrm{AcH}$ chimeric protein mutants with altered bactericidal activity. Appl Environ Microbiol 64, 1997-2005.

Nes, I. F. \& Holo, H. (2000). Class II antimicrobial peptides from lactic acid bacteria. Biopolymers 55, 50-61.

Nes, I. F., Holo, H., Fimland, G., Hauge, H. H. \& Nissen-Meyer, J. (2002). Unmodified peptide-bacteriocins (class II) produced by lactic acid bacteria. In Peptide Antibiotics, Discovery, Modes of Action and Application. Edited by C. J. Dutton, M. A. Haxell, H. A. I. McArthur \& R. G. Wax. New York: Marcel Decker.

Nieto Lozano, J. C., Nissen-Meyer, J., Sletten, K., Peláz, C. \& Nes, I. F. (1992). Purification and amino acid sequences of a bacteriocin produced by Pediococcus acidilactici. J Gen Microbiol 138, 1985-1990.

Nissen-Meyer, J., Holo, H., Håvarstein, L. S., Sletten, K. \& Nes, I. F. (1992). A novel lactococcal bacteriocin whose activity depends on the complementary action of two peptides. J Bacteriol 174, 5686-5692.

Nissen-Meyer, J., Håvarstein, L. S., Holo, H., Sletten, K. \& Nes, I. F. (1993). Association of the lactococcin A immunity factor with the cell membrane: purification and characterization of the immunity factor. J Gen Microbiol 139, 1503-1509.

Quadri, L. E. N., Sailer, M., Roy, K. L., Vederas, J. C. \& Stiles, M. E. (1994). Chemical and genetic characterization of bacteriocins produced by Carnobacterium piscicola LV17B. J Biol Chem 269, 12204-12211.

Quadri, L. E. N., Sailer, M., Terbiznik, M. R., Roy, K. L., Vederas, J. C. \& Stiles, M. E. (1995). Characterization of the protein conferring immunity to the antimicrobial peptide carnobacteriocin B2 and expression of carnobacteriocins B2 and BM1. J Bacteriol 177, 1144-1151.

Quadri, L. E. N., Kleerebezem, M., Kuipers, O. P., de Vos, W. M., Roy, K. L., Vederas, J. C. \& Stiles, M. E. (1997). Characterization of a locus from Carnobacterium piscicola LV17B involved in bacteriocin production and immunity: evidence for global inducer-mediated transcription regulation. J Bacteriol 179, 61636171.

Ramnath, M., Beukes, M., Tamura, K. \& Hastings, J. W. (2000). Absence of a putative mannose-specific phosphotransferase system enzyme IIAB component in a leucocin A-resistant strain of Listeria monocytogenes, as shown by two-dimensional sodium 
dodecyl sulfate-polyacrylamide gel electrophoresis. Appl Environ Microbiol 66, 3098-3101.

Shepard, D. B. \& Gilmore, M. S. (1995). Electroporation and efficient transformation of Enterococcus faecalis grown in high concentration of glycine. In Methods in Molecular Biology, vol. 47, Electroporation Protocols for Microorganisms, pp. 217-226. Edited by J. A. Nickoloff. Totowa, NJ: Humana Press.

Stoffels, G., Nissen-Meyer, J., Gudmundsdottir, A., Sletten, K., Holo, H. \& Nes, I. F. (1992). Purification and characterization of a new bacteriocin isolated from a Carnobacterium sp. Appl Environ Microbiol 58, 1417-1422.

Tichaczek, P. S., Vogel, R. F. \& Hammes, W. P. (1993). Cloning and sequencing of curA encoding curvacin $\mathrm{A}$, the bacteriocin produced by Lactobacillus curvatus LTH1174. Arch Microbiol 160, 279-283.

Tichaczek, P. S., Vogel, R. F. \& Hammes, W. P. (1994). Cloning and sequencing of sakP encoding sakacin $\mathrm{P}$, the bacteriocin produced by Lactobacillus sake LTH673. Microbiology 140, 361-367.

Tomita, H., Fujimoto, S., Tanimoto, K. \& Yasuyoshi, I. (1996). Cloning and genetic organization of the bacteriocin 31 determinant encoded on the Enterococcus faecalis pheromoneresponsive conjugative plasmid pYI17. J Bacteriol 178, 3585-3593.

van de Guchte, M., van der Vossen, J. M. B. M., Kok, J. \& Venema, G. (1989). Construction of a lactococcal expression vector: expression of hen egg white lysozyme in Lactococcus lactis subsp. lactis. Appl Environ Microbiol 55, 224-228.

Vaughan, A., Eijsink, V. G. H., O'Sullivan, T. F., O’Hanlon, K. \& van Sinderen, D. (2001). An analysis of bacteriocins produced by lactic acid bacteria isolated from malted barley. J Appl Microbiol 91, 131-138.

Venema, K., Haverkort, R. E., Abee, T., Haandrikman, A. J., Leenhouts, K. J., de Leij, L., Venema, G. \& Kok, J. (1994). Mode of action of LciA, the lactococcin A immunity protein. Mol Microbiol 14, 521-532.

Venema, K., Kok, J., Marugg, J. D., Toonen, M. Y., Ledeboer, A. M., Venema, G. \& Chikindas, M. L. (1995). Functional analysis of the pediocin operon of Pediococcus acidilactici PAC1.0: PedB is the immunity protein and PedD is the precursor processing enzyme. Mol Microbiol 17, 515-522.

Wang, Y., Henz, M. E., Fregeau Gallagher, N. L., Chai, S., Gibbs, A. C., Liang, Z. Y., Stiles, M. E., Wishart, D. S. \& Vederas, J. C. (1999). Solution structure of carnobacteriocin B2 and implications for structure-activity relationships among type IIa bacteriocins from lactic acid bacteria. Biochemistry 38, 15438-15447.

Watson, R. M., Woody, R. W., Lewis, R. V., Bohle, D. S., Andreotti, A. H., Ray, B. \& Miller, K. W. (2001). Conformational changes in pediocin $\mathrm{AcH}$ upon vesicle binding and approximation of the membrane-bound structure in detergent micelles. Biochemistry 40, 14037-14046.

Yan, L. Z., Gibbs, A. C., Stiles, M. E., Wishart, D. S. \& Vederas, J. C. (2000). Analogues of bacteriocins: antimicrobial specificity and interactions of leucocin A with its enantiomer, carnobacteriocin B2, and truncated derivatives. J Med Chem 43, 4579-4581.

Received 25 April 2002; revised 23 July 2002; accepted 5 August 2002. 